\title{
Characteristic features of the life-meaning and value orientations of sales department employees during the transformation of professional activity
}

\author{
Liudmila Kruteleva ${ }^{1, *}$ and Zhanna Kara $^{1}$
}

${ }^{1}$ Southern Federal University, 116, Dneprovsky Pereulok, office 402, Rostov-on-Don, 344065, Russia

\begin{abstract}
The current threat of the COVID-19 pandemic has crucially changed the familiar life and caused the shift in all spheres including the professional one. Ambiguity of the nearest future and anxiety about oneself health have shifted the sphere of trade into online format. The purpose of the research was to study correlations between life-meaning and value orientations and professional motivation, and ambiguity tolerance of sales department employees. The theoretical grounds of the research are the concepts of meaning-value sphere and life-meaning orientations (Abakumova I.V., Baumeister R.F., Kruteleva L.J., Leontiev D.A., Rokeach M., Yanitskiy M.S., Seryy A.V., Schwartz S.H., etc.); professional motivation (Abakumova I.V., Barabanshchikova V.V., Ivanova S.A., Klimova O.A., etc.) and ambiguity tolerance (Asmolov A.G., Shekter E.D., Chernorizov A.M., etc.). The sample comprised 49 sales department employees aged 22 to 49 with the professional experience from 1 to 9 years. The empirical research includes the following techniques (adapted into Russian): Purpose-in-Life Test, Rokeach Value Survey, Career Anchors, Work Motivation Inventory, and Multiple Stimulus Types Ambiguity Tolerance Scale-I. The results indicate the life-meaning orientations and the general level of life meaningfulness do not correlate to ambiguity tolerance. Values of private life help to cope with the changing circumstances. The forced transformation of the professional activity frustrates respondents to achieve professional self-realization, facilitates the sales department employees to promote new products and services.
\end{abstract}

\section{The transformation of professional activity as a forced reality}

The year of 2020 has made rapid and essential changes in the structure of interaction between people: any personal communication "face to face" almost instantly switched to an online format not only in the personal, but also in the professional sphere. It is no exaggeration to say that today digital technologies have embraced the entire society and almost the entire world. And such an abrupt transition was partly a natural process, but to a greater extent it was a forced measure caused by the outbreak and the global distribution of the new coronavirus infection COVID-19, and the subsequent voluntary lockdown.

* Corresponding author: kruteleva@sfedu.ru 
The widespread forced transition to the online communication led to a restructuring of all relationships and the professional activity most significantly. One of the areas most affected by changes has become the service industry and, in particular, the sphere of trade.

The most important resource of any organization is its staff. The success of trading companies, in particular, directly depends on human resources: on the level of the passion for work, on the personal potential of each employee, on his/her working efficiency, responsibility, etc. In this context it becomes obvious that it is necessary to study the characteristics of professional motivation and ambiguity tolerance and to correlate them with basic personality characteristics such as life-meaning and value orientations during the period of transformation of professional activity.

The purpose of the research is to study life-meaning and value orientations, professional motivation, and ambiguity tolerance of sales department employees in the period of transformation of professional communication.

The hypothesis of the research: we assume that there are probably statistically highly significant correlations between the components of life-meaning and value orientations and the components of professional motivation and ambiguity tolerance of sales department employees.

\section{Materials and research methods}

\subsection{Theoretical grounds of the research}

Our theoretical research of meaning-value sphere and life-meaning orientations of a person is based on the analysis of works by Abakumova I.V., Ermakov P.N., Godunov M.V (2018) [1]; Baumeister R.F., von Hippel W. (2020) [2], Baumeister R.F. (2005, 1991) [3, 4]; Kruteleva L.J., Abakumova I.V. (2013) [5]; Leontiev D. (2020, 2017, 2013) [6-8]; Rokeach M. (1985) [9]; Utyuganov A.A., Yanitskiy M.S., Seryy A.V. (2019) [10]; Vecchione M., Schwartz S.H., Davidov E., Cieciuch J., Alessandri G., Marsicano G. (2020) [11] and other scientists.

The characteristic features of professional motivation are investigated in works by Abakumova I., Kukulyar A., Kolenova A. (2020) [12]; Endriulaitienè A., Morkevičiūtè M. (2020) [13]; Chang Y., Hou R.-J., Wang K., Cui A.P., Zhang C.-B. (2020) [14]; Lin C., Li X., Lam L.W (2020) [15]; Barabanshchikova V.V., Ivanova S.A., Klimova O.A. (2018) [16]; Nevryuev A.N., Gulevich O.A., Nekrasova E.A. (2018) [17] and others.

In the context of the given research it is also necessary to analyze researches of ambiguity tolerance. The psychological aspects of the phenomenon are studied by Asmolov G.A., Asmolov A.G. (2019, 2009) [18, 20]; Asmolov A.G., Shekter E.D., Chernorizov A.M. (2017) [19]; Singh P., Singh S., Sohal M., Dwivedi Y.K., Kahlon K.S., Sawhney R.S. (2020) [21] and other researchers.

\subsection{Research methods and techniques}

The main methods of empirical research were questionnaire survey and testing. The data analysis consists of methods of qualitative analysis, descriptive statistics and statistical data processing methods.

The questionnaire survey was conducted to collect general demographic and social data about the respondents (name, gender, age, education, work experience and length of service).

To study meaning-value sphere of the respondents we applied the following techniques: Purpose-in-Life Test (J. Crumbaugh \& L. Maholick, modified by D.A. Leontiev) and Rokeach Value Survey (modified by A. Goshtautas, A.A. Semenov, V.A. Yadov). These 
diagnostic tools make it possible to identify the main life-meaning and value orientations of the respondents.

To study professional motivation we used: Career Anchors (E. Schein, adapted by V.A. Chiker, V.E. Vinokurova) and Work Motivation Inventory (C. Zamfir, modified by AA Rean). These diagnostic techniques made it possible to reveal the leading professional motives of the respondents and their social attitudes to their careers and the job in general.

Multiple Stimulus Types Ambiguity Tolerance Scale-I (McLain, validated by E.N. Osin) helped us to reveal the attitude of the respondents to the changing conditions of their professional activity and to determine their degree of openness to change.

In the context of online sales the study was conducted in the form of an individual work: all respondents were offered uniform test blanks. Each respondent required approximately 2 academic hours to answer all the questions.

The data processing included qualitative (analytical comparison) and quantitative (descriptive statistics) methods. Spearman's rank correlation analysis was used to reveal the correlations between studied phenomena. The level of statistical significance (p) was taken equal to 0.01 .

\subsection{The sample}

The study involved 49 individuals ( 27 men and 22 women) aged 22 to 49 . All the respondents work at the sales department of Leroy Merlin Vostok of the following positions:

- department manager - $16,33 \%$ (8 people);

- $\quad$ sales assistant $-28,57 \%$ (14 people);

- $\quad$ cashier - $28,57 \%$ (14 people);

- $\quad$ logistics specialist $-26,53 \%$ (13 people).

The respondents have the following levels of education: secondary professional education $(28,57 \%)$, incomplete higher education $(28,57 \%)$, higher education $(42,86 \%)$.

The professional experience in the field of sales varies from 1 to 9 years. The average length of service is 5 years.

The empirical art of the study was conducted in April 2020. The objectives of the study were clearly explained to the respondents and they were notified of further use and publication of the results. All respondents voluntarily agreed to participate in the study.

\section{The results of the research}

\subsection{The research of the sense-value sphere of the sales department employees}

The results of the study of the life-meaning orientations of the respondents are presented in Table 1.

Table 1. Results by Purpose-in-Life Test (J. Crumbaugh \& L. Maholick, modified by D.A. Leontiev), in points.

\begin{tabular}{|l|c|c|}
\hline \multicolumn{1}{|c|}{ Scales } & Results & Standard deviation \\
\hline General level of Life Meaningfulness & 93.29 & 15.47 \\
\hline Purposes in Life & 28.39 & 5.82 \\
\hline Process of Life & 27.47 & 6.02 \\
\hline Results of Life & 22.41 & 4.86 \\
\hline Locus of Control "Self" & 19.67 & 3.78 \\
\hline Locus of Control "Life" & 27.86 & 5.45 \\
\hline
\end{tabular}


Considering the obtained data, we can say that, in general, all the components of the lifemeaning orientations of respondents, including the general level of life meaningfulness, are within the average numbers, taking into account the standard deviation, which here has slightly lower values than in the given normative indicators (this fact points to the homogeneity of the sample of the respondents).

In the whole sample, $12,24 \%$ (6 people) of respondents have got the general level of life meaningfulness which is above the average and $16,33 \%$ ( 8 people) of respondents have got the general level of life meaningfulness which is below the average.

To identify the structure of the life-meaning orientations of the respondents the obtained data of five scales were converted into absolute values (Fig. 1)

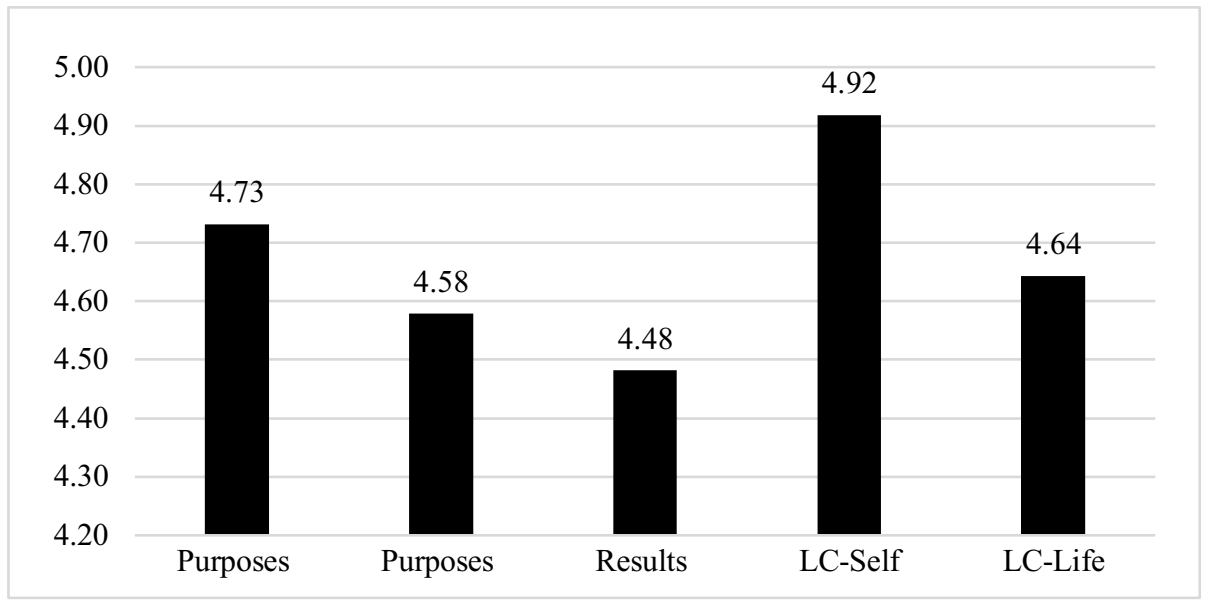

Fig. 1. The structure of life-meaning orientations, in absolute values.

The results of the study of the system of value orientations of respondents are presented in Table 2.

Table 2. Results by Rokeach Value Survey (modified by A. Goshtautas, A.A. Semenov, V.A. Yadov), ranks.

\begin{tabular}{|c|c|c|c|}
\hline The terminal values & Average rank & The Instrumental Values & Average rank \\
\hline Active life & 6 & Cleanliness & 12 \\
\hline Wisdom & 4 & Politeness & 3 \\
\hline Health & 1 & High maintenance (Ambition) & 17 \\
\hline Interesting job & 10 & Cheerfulness & 6 \\
\hline Beauty of nature and art & 17 & Discipline (Obedience) & 13 \\
\hline Love & 2 & Independence & 2 \\
\hline Financially secure life & 7 & Intransigence on human & 18 \\
\hline True friendship & 11 & failures & 8 \\
\hline Social Recognition & 14 & Responsibility & 4 \\
\hline Knowledge & 12 & Rationality & 5 \\
\hline Productive life & 9 & Self-Control & 9 \\
\hline Development & 13 & Courage & 11 \\
\hline Pleasure & 15 & Inflexible will & 10 \\
\hline
\end{tabular}




\begin{tabular}{|c|c|c|c|}
\hline Freedom & 8 & Tolerance & 15 \\
\hline Happy family life & 5 & Broad-Mindedness & 16 \\
\hline Happiness of others & 18 & Honesty & 1 \\
\hline Creativity & 16 & Effectiveness & 14 \\
\hline Self-Respect & 3 & Sensibility & 7 \\
\hline
\end{tabular}

It can be seen from the obtained distribution of terminal values that the most significant values for these respondents are "health", "love", "self-respect", "wisdom", "happy family life" and "active life". As the least significant values the respondents referred to "happiness of others", "beauty of nature and art", "creativity", "pleasure", "social recognition" and "development".

The distribution of instrumental values showed that these respondents are ready to set goals and achieve terminal values by means of such values as "honesty", "independence", "politeness", "responsibility", "rationality" and "cheerfulness". The respondents give the least importance to such instrumental values as "intransigence on human failures", "high maintenance", "broad-mindedness", "tolerance", "effectiveness" and "discipline".

\subsection{The research of the motivation sphere and ambiguity tolerance of the sales department employees}

The study of the motives of professional activity (career orientations) made it possible to single out the average group profile of the respondents, presented in Figure 2.

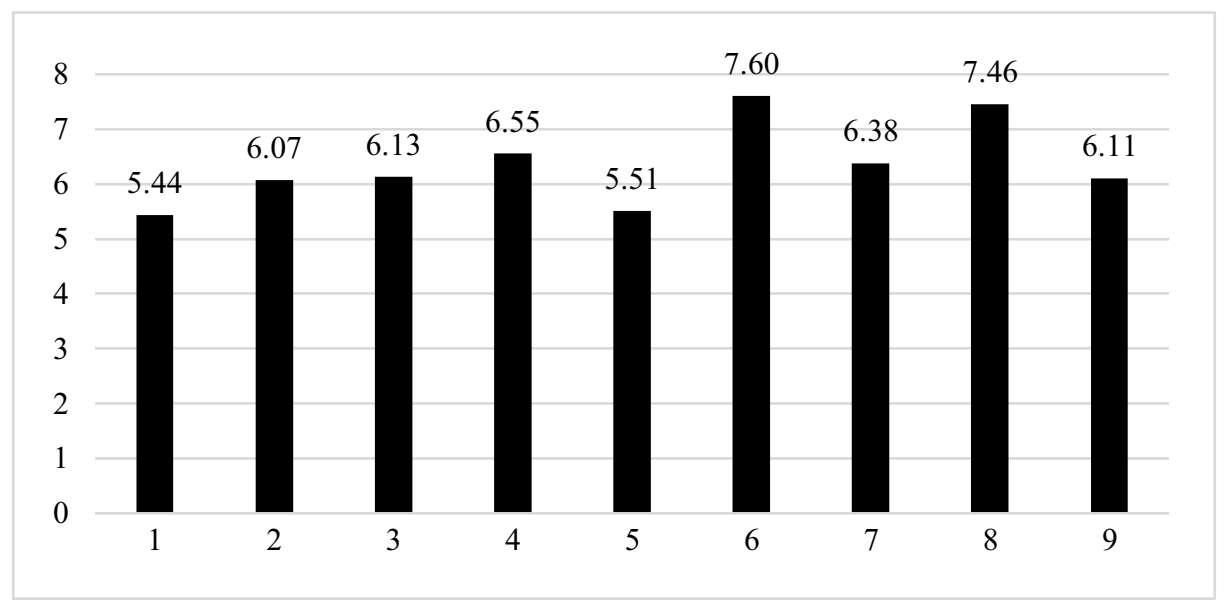

Fig. 2. Results by Career Anchors (E. Schein, adapted by V.A. Chiker, V.E. Vinokurova), in points.

Where: 1 - Technical and Functional Competence; 2 - General Management; 3 Autonomy and Independence; 4 - Stability of Work; 5 - Stability of Place of Residence; 6 Service and Dedication to a Cause; 7 - Pure Challenge; 8 - Integration of Life Styles; 9 Entrepreneurial Creativity.

These findings clearly show that "service and dedication to a cause" and "integration of life styles" are the leading motives of the professional activity of the respondents. "Stability of place of residence" and "technical and functional competence" have got the least significance.

The motivational complex of personality of the respondents in relation to their professional activity is shown in Figure 3. The received results correspond to the standard 
indicators given by the authors of the techniques and there are within the average level of intensity.

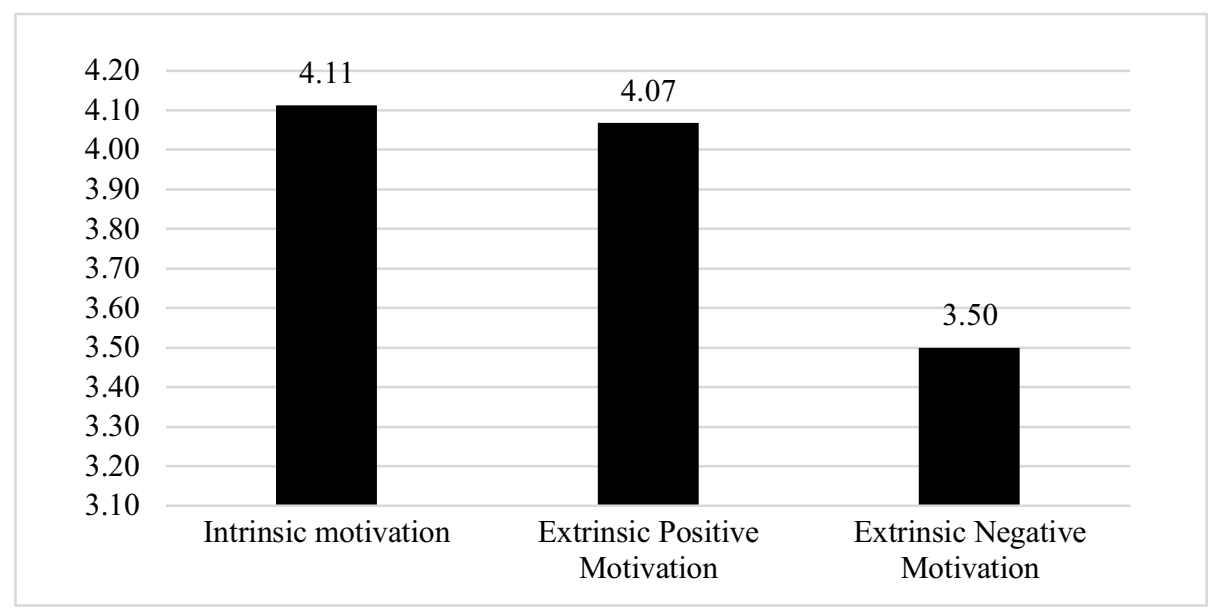

Fig. 3. Results by Work Motivation Inventory (C. Zamfir, modified by AA Rean), in points.

The study of the attitude of the respondents to the changing conditions of their professional activity and their degree of openness to change is presented in Table 3.

Table 3. Results by Multiple Stimulus Types Ambiguity Tolerance Scale-I (McLain, validated by E.N. Osin), in points.

\begin{tabular}{|l|c|c|}
\hline \multicolumn{1}{|c|}{ Scales } & Results & Average Indicator \\
\hline Attitude to novelty & 13.47 & 13.92 \\
\hline Attitude to complex tasks & 30.35 & 33.64 \\
\hline Attitude to uncertain situations & 39.43 & 38.57 \\
\hline Preference for ambiguity & 46.37 & 52.61 \\
\hline Ambiguity tolerance & 36.88 & 47.4 \\
\hline Overall score & 83.24 & 100 \\
\hline
\end{tabular}

The obtained data indicate that such scales as "attitude to novelty", "attitude to complex tasks" and "attitude to uncertain situations" are within the average values, while scales of "preference for ambiguity", "ambiguity tolerance" and "overall score" are slightly reduced.

\subsection{The results of correlation analysis}

We carried out a correlation analysis of the findings received by primary data processing to confirm our hypothesis that "there are probably statistically highly significant correlations between the components of life-meaning and value orientations and the components of professional motivation and ambiguity tolerance of sales department employees". The revealed statistically highly significant correlations between the studied phenomena are presented in Table 4.

Table 4. Spearman's rank correlation coefficients $(\mathrm{N}=49, \mathrm{p}<0,00100)$.

\begin{tabular}{|c|c|c|}
\hline Parameter 1 & Parameter 2 & r \\
\hline Active life & General Management & -0.401 \\
\hline Active life & Pure Challenge & -0.390 \\
\hline
\end{tabular}




\begin{tabular}{|c|c|c|}
\hline Interesting job & Stability of Work & -0.496 \\
\hline Love & Intrinsic motivation & 0.459 \\
\hline Freedom & Extrinsic Positive Motivation & 0.396 \\
\hline True friendship & Attitude to novelty & 0.374 \\
\hline Values of private life & Service and Dedication to a Cause & 0.456 \\
\hline Particular values & Intrinsic motivation & -0.391 \\
\hline Abstract values & Intrinsic motivation & 0.393 \\
\hline Values of private life & Extrinsic Positive Motivation & 0.379 \\
\hline Professional self-realization & Attitude to novelty & -0.382 \\
\hline Values of private life & Attitude to novelty & 0.430 \\
\hline Values of private life & Preference for ambiguity & 0.390 \\
\hline Discipline & Technical and Functional Competence & 0.401 \\
\hline Ethic values & Entrepreneurial Creativity & 0.384 \\
\hline Values of self-actualization & Extrinsic Positive Motivation & 0.376 \\
\hline Entrepreneurial Creativity & Preference for ambiguity & 0.382 \\
\hline
\end{tabular}

The conducted analysis did not reveal statistically highly significant correlations between the components of life-meaning orientations and professional motivation, as well as components of ambiguity tolerance among the sales department employees.

\section{Discussion}

Analyzing the characteristic features of the meaning-value sphere of the sales department employees, it is necessary to pay attention to the following aspects.

1. The general level of life meaningfulness, like all other components of life-meaning orientations, have average values, got close to the lower limit of the norm. These results indicate that, on the whole, the respondents have quite a reasonable and responsible attitude to themselves and their lives and at the same time they do not descend into deep reflections.

The analysis revealed the following structure of life-meaning orientations:

Locus of Control "Self" > Purposes in Life> Locus of Control "Life"> Process of Life> Results of Life

This structure indicates that for the surveyed respondents above all things it is important to realize that they are responsible for their lives and for the events that happen to them. The presence of goals in the future and the fact that life can be controlled in general have also got a special importance for them. They think about the present and passed periods of life and the achieved results least of all.

The structure of life-meaning orientations corresponds to the leading value orientations. Thus, it can be assumed that "a man of character" self-concept is supported by such values as "health", "love" and "self-respect". Goals' setting and their achievement are also carried out by means of "self-respect", striving for "active life" and family support ("love" and "happy family life"), as well as relying on their personal experience ("wisdom"). And at the same time these respondents will honestly, responsibly, and rationally strive to achieve their goals.

It is important to note that in the period of the pandemic and self-isolation such terminal values as "happiness of others", "beauty of nature and art", "creativity", "pleasure", "social recognition" and "development" are of little importance to the respondents. Striving to cope with the situation of changing work conditions and achieve their goals respondents are ready 
to reconcile themselves to "intransigence on human failures", and have reduced their demands for life ("high maintenance"), and the desire to respect the point of view of others ("broad-mindedness"). The quality of their work has no special significance for them ("effectiveness" and "discipline").

2. Describing the respondents on basis of the obtained distribution of the motives of professional activity we can say that their main goal is to serve the society and the desire to realize their potential. They try to be of maximum benefit to people, however it is of great importance for them to see the particular results of their work. Their lifestyle includes a reasonably harmonious combination of personal life and professional activity. And they do not strive to "climb up" the career ladder.

The motivational complex of their professional activity has got quite equally expressed intrinsic and extrinsic (positive and negative) motivation. Thus, professional activity in itself as well as motives of social prestige and escape of punishment are of great importance for the respondents and gives them the opportunity for self-realization.

3. The research of ambiguity tolerance has revealed that the respondents have quite a calm attitude to novelty, complex tasks, and uncertain situations. However, at the time of diagnosis they are challenged with needs for a greater degree of clarity and certainty of the life situation and its immediate prospects. The fact is explained by the fact that the study was carried out during the COVID-19 pandemic and the global ambiguity of the life situation.

4. The correlation analysis allowed us to identify highly significant correlations only between the value orientations and the components of professional motivation and ambiguity tolerance of sales department employees. The statistically highly significant correlations between the components of life-meaning and other studied phenomena have not been revealed. This fact partially proves our hypothesis.

\section{Conclusion}

The research has revealed that the time perspective of a person and his/her focus of locus of control (internal locus of control - external locus of control) have no correlations to ambiguity tolerance, i.e. it does not depend on the level of life meaningfulness.

The sales department employees can cope with the forced transformation of their professional activity and its transition to the online communication by means of support of their values of private life (love, happy family life, true friendship, etc.). But the changing conditions of the professional activity prevent them from professional self-realization.

The professional motivation is maintained by abstract values and values of private life as well as discipline and ethic values.

And the existing situation helps the sales department employees to promote new products and services.

\section{References}

1. I.V. Abakumova, P.N. Ermakov, M.V. Godunov, Psychology in Russia: State of the Art 11(4), 200-210 (2018)

2. R.F. Baumeister, W. von Hippel, Evolutionary Studies in Imaginative Culture 4(1), 118 (2020)

3. R.F. Baumeister, The cultural animal: Human nature, meaning, and social life (Oxford University Press, NY, 2005)

4. R.F. Baumeister, The Meanings of Life (Guilford, New York, 1991) 
5. L.J. Kruteleva, I.V. Abakumova, 5th Congress of the Russian-Psychological-Society. Procedia Social and Behavioral Sciences 86, 35-41 (2013)

6. D. Leontiev, Evolutionary Studies in Imaginative Culture 4(1), 31-33 (2020)

7. D. Leontiev, Journal of Constructivist Psychology 30(1), 74-81 (2017)

8. D.A. Leontiev, Journal of Positive Psychology 8(6), 459-470 (2013)

9. M. Rokeach, Journal of Social Issues 41(1), 153-171 (1985)

10. A.A. Utyuganov, M.S. Yanitskiy, A.V. Seryy, Science for Education Today 9(1), 76-92 (2019)

11. M. Vecchione, S.H. Schwartz, E. Davidov, et al, Journal of Personality 88(3), 447-463 (2020)

12. I. Abakumova, A. Kukulyar, A. Kolenova, 13th International Scientific and Practical Conference on State and Prospects for the Development of Agribusiness, INTERAGROMASH 2020 E3S Web of Conferences 175, 15009 (2020)

13. A. Endriulaitienè, M. Morkevičiūte, Journal of Psychology: Interdisciplinary and Applied 154(6), 446-465 (2020)

14. Y. Chang, R.-J. Hou, K. Wang, A.P. Cui, C.-B. Zhang, Computers in Human Behavior 109, 106360 (2020)

15. C. Lin, X. Li, L.W. Lam, Human Resource Management 59(4), 311-325 (2020)

16. V.V. Barabanshchikova, S.A. Ivanova, O.A. Klimova, Psychology in Russia: State of the Art 11(3), 69-85 (2018)

17. A.N. Nevryuev, O.A. Gulevich, E.A. Nekrasova, Psikhologicheskii Zhurnal 39(4), $17-$ 26 (2018)

18. G.A. Asmolov, A.G. Asmolov, Voprosy Psikhologii 4, 3-28 (2019)

19. A.G. Asmolov, E.D. Shekter, A.M. Chernorizov, Voprosy Psikhologii 4, 3-26 (2017)

20. A.G. Asmolov, G.A. Asmolov, Voprosy Psikhologii 3, 3-15 (2009)

21. P. Singh, S. Singh, M. Sohal, Y.K. Dwivedi, K.S. Kahlon, R.S. Sawhney, Asian Journal of Psychiatry 54, 102280 (2020) 